\title{
A LONG-TERM FORECASTING MODEL OF ELECTRICITY CONSUMPTION VOLUME ON THE EXAMPLE OF UPS OF THE URAL WITH THE HELP OF HARMONIC ANALYSIS OF A TIME SERIES
}

\author{
V.G. Mokhov ${ }^{1}$, T.S. Demyanenko ${ }^{1}$ \\ ${ }^{1}$ South Ural State University, Chelyabinsk, Russian Federation \\ E-mails: mokhovvg@susu.ru, demianenkots@susu.ru
}

In this article, the model of forecasting of electricity consumption volume is analyzed on the basis of harmonic analysis of a time series. Previously, we establish the presence of a trend component described by a second-order polynomial. Based on the construction of the autocorrelation function, the periodicity of the time series of electricity consumption volume is proved, with periods equal to 1 year and 1 week, due to decrease in electricity consumption in summer because of increase in daylight hours and decrease in production on weekends. The model is tested on actual hourly data of United Energy System of the wholesale market for electricity and power in Russia. The model is tested for adequacy using Fisher's criterion and the coefficient of determination. The introduction of two harmonic components (annual and weekly ones) instead of the generally accepted one reduces the approximation error for the current model from $2,25 \%$ to $2,08 \%$, which provides increased energy efficiency for consumers while reducing the fines of the balancing market. The proposed scientific tools are recommended in the entity's operating activity of electric power to forecast the major energy market parameters in order to reduce the fines by improving the accuracy of forecasts.

Keywords: forecasting models; main parameters; energy market; harmonic analysis.

\section{Introduction}

In the energy market, the planned consumption volumes are formed on the basis of bilateral agreements. In reality, the actual electric energy consumption volume is practically always different from the planned one. Deviations from planned indexes are sold in the balancing market (BM), and the System Operator of the Unified Energy System of Russia (SO) regularly conducts an additional competitive selection of providers' applications, which is based on the current forecast electricity consumption [1].

In Russian conditions, the problem of long-term forecasting of the basic parameters of the electricity market is one of the most pressing.

\section{Specification of a Type of the Time Series Model of Electricity Consumption Volume}

A graphical analysis of a time series of electricity consumption volume indicates the presence of seasonal fluctuations, a period of which is one year; the most important "outliers" in the dynamics of a time series take place during the transition from the fourth quarter to the first one. Besides the fluctuations within a period which is equal to one year, seasonal fluctuations are observed with the help of detailed consideration, the period of which is equal to seven days. It happened due to a high electricity consumption at the beginning of workweek and a decrease connected with the beginning of weekends [2]. The additive model of a time series is selected for investigation, since the characteristics of 
frequency fluctuations are approximately constant:

$$
Y=T+S+E
$$

where $T$ is a tendency component of a time series, $S$ is a seasonal component of a time series, $E$ represents random fluctuations.

\section{Modelling Seasonal Fluctuations of a Time Series}

Autocorrelation is a measure of an internal correlation within a time series. This is a way to measure and explain an internal connection between the observations in a time series, so it is advisable to use exactly autocorrelation to identify the seasonal component of a time series.

An analysis of the autocorrelation function and correlograms allow to reveal the structure of the series, i.e. to determine the presence of a particular component in the series. Autocorrelation functions are found for the lag range. Linear autocorrelation coefficients characterize the tightness of only a linear connection between current and previous series levels. Therefore, according to the autocorrelation coefficients, we can estimate only the presence or absence of (linear or nearly linear) dependence. To check whether a series includes a non-linear tendency, it is necessary to calculate the linear autocorrelation coefficients for a time series which consists of the logarithms of the initial levels. Non-zero values of the autocorrelation coefficients indicate the presence of a non-linear tendency $[3$, $4]$.

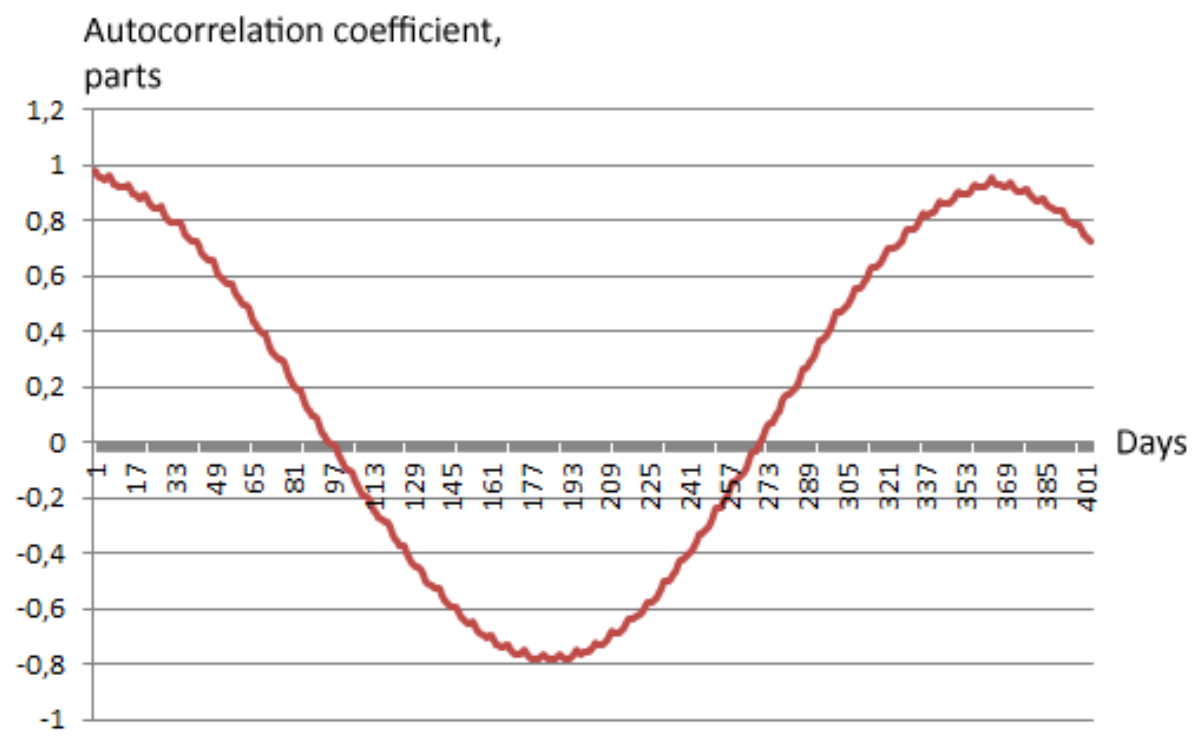

Fig. 1. Correlogram of electricity consumption volume in the range of lag from 1 to 401 for the UPS of the Ural data from 2009 to 2015

All of the autocorrelation coefficients for the logarithms of the series levels are different from non-zero values for the investigated time series, therefore, the non-linear dependence is present. The existence of seasonal fluctuations with annual and weekly periods was proved, therefore, the seasonal component can be regarded as a harmonic fluctuating process. 
For the time series of electricity consumption volume, the model of periodic fluctuations can take the following form:

$$
\begin{gathered}
y_{t}=a_{0}+a_{1} \cdot \cos \left(t \frac{2 \pi}{T_{1}}\right)+b_{1} \cdot \sin \left(t \frac{2 \pi}{T_{1}}\right)+a_{2} \cdot \cos \left(t \frac{2 \pi}{T_{2}}\right)+a_{2} \cdot \sin \left(t \frac{2 \pi}{T_{2}}\right), \\
a_{0}=\bar{y}, a_{1}=\frac{2}{T_{1}} \sum_{i=1}^{n}\left(y_{t}\right) \cdot \cos \left(t \frac{2 \pi}{T_{1}}\right), b_{1}=\frac{2}{T_{1}} \sum_{i=1}^{n}\left(y_{t}\right) \cdot \sin \left(t \frac{2 \pi}{T_{1}}\right), \\
a_{2}=\frac{2}{T_{2}} \sum_{i=1}^{n}\left(y_{t}\right) \cdot \cos \left(t \frac{2 \pi}{T_{2}}\right), b_{2}=\frac{2}{T_{2}} \sum_{i=1}^{n}\left(y_{t}\right) \cdot \sin \left(t \frac{2 \pi}{T_{2}}\right),
\end{gathered}
$$

where $T$ is the period length. In this case, $1=365,2=7$, as it is confirmed by the autocorrelation research.

After certain calculations, the equation takes the form

$$
\begin{array}{rl}
y_{t}=68 & 766+92183 \cos \left(t \frac{2 \pi}{365}\right)+16740 \sin \left(t \frac{2 \pi}{365}\right)+ \\
+ & 8931 \cos \left(t \frac{2 \pi}{7}\right)+4503,5 \sin \left(t \frac{2 \pi}{7}\right) .
\end{array}
$$

The average error of approximation of the obtained model is 3,32\%. Graphic forecasting results are shown in Fig. 2.

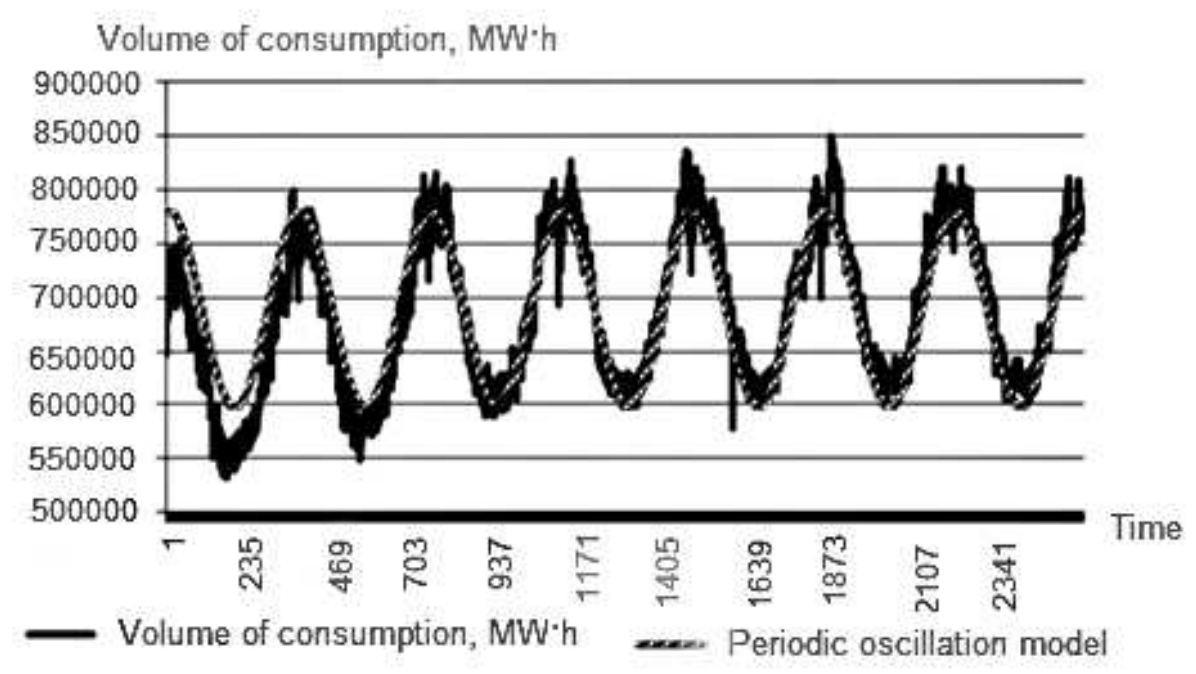

Fig. 2. The time series of electricity consumption volume according to the UPS of the Urals data from 2009 to 2015 and the harmonic model of periodic fluctuations

According to F-Fisher criterion, the obtained harmonic model is statistically significant, and the Student's t-criterion confirms significance of the coefficients [5].

\section{The Model of Long-Term Forecasting Based on Harmonic Analysis}

In the article [2], the finding of a trend component was considered. A second-order polynomial describes the most accurate source data, numerical characteristics of the 
model confirm it, namely, the smallest error of approximation and the greatest coefficient of determination. The following equation for forecasting of the electricity consumption volume was constructed as a result of combining the obtained models of trend and seasonal components:

$$
\begin{aligned}
y_{t}=-0,0198 x^{2}+ & 82,53 x+621322+92183 \cos \left(t \frac{2 \pi}{365}\right)+16740 \sin \left(t \frac{2 \pi}{365}\right)+ \\
& +8931 \cos \left(t \frac{2 \pi}{7}\right)+4503,5 \sin \left(t \frac{2 \pi}{7}\right) .
\end{aligned}
$$

The average error of approximation of the constructed model is 2,08\%. Graph of the obtained model and the initial time series is shown in Fig. 3.

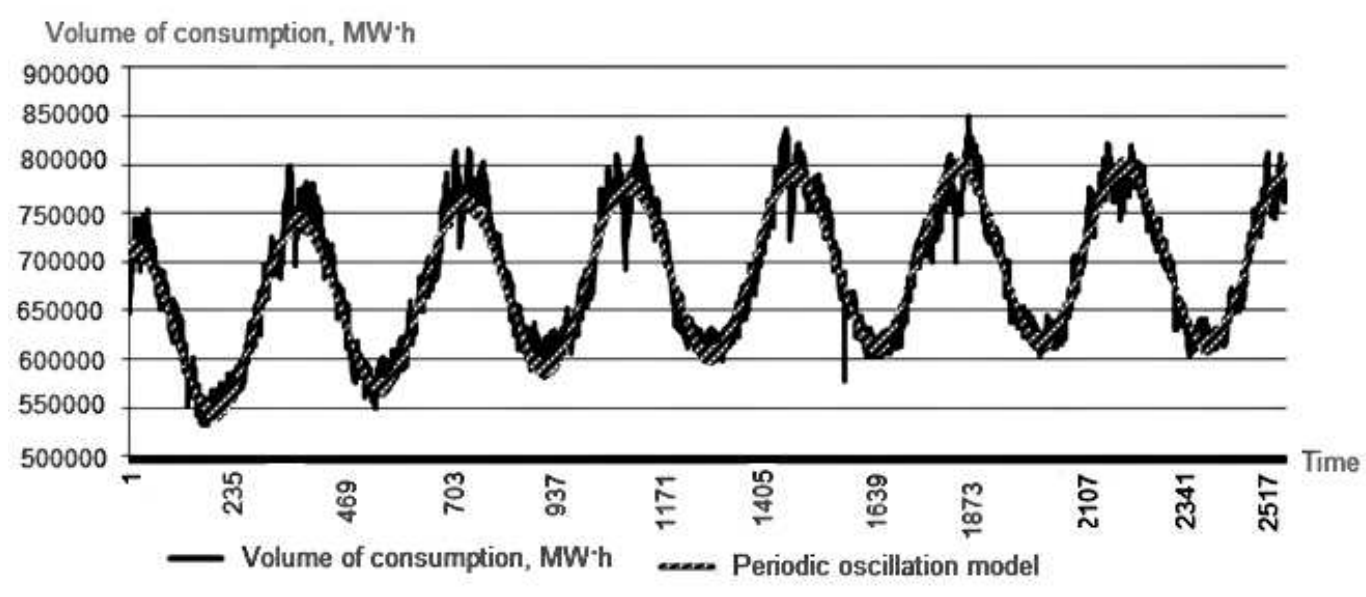

Fig. 3. The time series of electricity consumption according to the UPS of the Ural data from 2009 to 2015 and the harmonic model of seasonal fluctuations taking into account the tendency component

\section{Conclusions}

We consider the model of long-term forecasting of capacity of the electric power market using harmonic analysis of a time series. Also, we calculate indicators and criteria, which prove efficiency and adequacy of the obtained model. The periodicity of a time series of electric energy consumption is proved, periods are 1 year and 1 week. We construct the additive model of a time series, which takes into account the tendency and harmonic components. The average approximation error is $2,08 \%$. The totality of these facts suggests that the developed model is suitable for long-term planning of the electricity and power market.

\section{References}

1. Mokhov V.G., Demyanenko T.S. Modelling of the Time Series Digressions by the Example of the UPS of the Ural. Bulletin of the South Ural State University. Series: Mathematical Modelling. Programming and Computer Software, 2015, vol. 8, no. 4, pp. 127-130. DOI: $10.14529 / \mathrm{mmp} 150412$

2. Mokhov V.G., Demyanenko T.S. The Construction of the Trend Component of the Additive Model of Long-Term Forecasting of the Wholesale Market of Electric Energy and Power of Russia Using the Example of the Ural Energy System. Bulletin of the South Ural State University. Series: Economics and Management, 2018, vol. 12, no. 2, pp. 80-87. 
3. Singh S. Pattern Modelling in Time-Series Forecasting. Cybernetics and Systems-An International Journal, 2000, vol. 31, no. 1, pp. 49-65.

4. Nogales F.J., Conejo A.J. Electricity Price Forecasting Through 138 Transferfunction Models. Journal of the Operational Research Society, 2006, vol. 57, no. 4, pp. 350-356.

5. Conejo A.J. Day-Ahead Electricity Price Forecasting Using the Wavelet Transform and ARIMA Models. IEEE Transaction on Power Systems, 2005, vol. 20, no. 2, pp. 1035-1042.

Received March 20, 2020

УДК 330.322.013+001.895

DOI: $10.14529 / \mathrm{mmp} 200308$

\title{
МОДЕЛЬ ДОЛГОСРОЧНОГО ПРОГНОЗИРОВАНИЯ ОБЪЕМА ПОТРЕБЛЕНИЯ ЭЛЕКТРОЭНЕРГИИ НА ПРИМЕРЕ ОЭС УРАЛА С ПОМОЩЬЮ ГАРМОНИЧЕСКОГО АНАЛИЗА ВРЕМЕННЫХ РЯДОВ
}

\author{
В.Г. Мохов ${ }^{1}$, Т.С. Демъяненко \\ ${ }^{1}$ Южно-Уральский государственный университет, г. Челябинск, \\ Российская Федерация
}

\begin{abstract}
В статье рассмотрена модель прогнозирования объемов потребления электроэнергии на основе гармонического анализа временных рядов. Ранее авторами было установлено наличие трендовой составляющей, описываемой полиномом второго порядка. На основе построения автокорреляционной функции была доказана периодичность временного ряда объема потребления электрической энергии, с периодами 1 год и 1 неделя, что обусловлено снижением электропотребления в летний период за счет увеличения светлого времени суток и снижением производства в выходные дни. Модель протестирована на фактических почасовых данных Объединенной энергосистемы Оптового рынка электроэнергии и мощности России. Модель проверена на адекватность с помощью критерия Фишера и коэффициента детерминации. Введение двух гармонических составляющих (годовой и недельной) вместо общепринятой одной снизило ошибку аппроксимации для текущей модели с 2,25\% до 2,08 \%, что обеспечит повышение энергоэффективности потребителей при снижении величины штрафов балансирующего рынка. Разработанный научный инструментарий рекомендуется в операционной деятельности субъектов электроэнергетики при прогнозировании основных параметров энергетического рынка для снижения штрафных санкций за счет повышения точности прогнозов.
\end{abstract}

Ключевые слова: модели прогнозирования; основные параметры; энергетический рынок; гармонический анализ.

\section{Литература}

1. Mokhov, V.G. Modeling of the Time Series Digressions by the Example of the UPS of the Ural / V.G. Mokhov, T.S. Demyanenko // Вестник ЮУрГУ. Серия: Математическое моделирование и программирование. - 2015. - Т. 8, № 4. - С. 127-130.

2. Мохов, В.Г. Построение трендовой составляющей аддитивной модели долгосрочного прогнозирования Оптового рынка электрической энергии и мощности России на примере Объединенной энергосистемы Урала / В.Г. Мохов, Т.С. Демьяненко // Вестник ЮУрГУ. Серия: Экономика и менеджмент. - 2018. - Т. 12, № 2. - С. 80-87. 
3. Singh, S. Pattern Modelling in Time-Series Forecasting / S. Singh // Cybernetics and Systems-AnInternational Journal. - 2000. - V. 31, № 1. - P. 49-65.

4. Nogales, F.J. Electricity Price Forecasting Through 138 Transferfunction Models / F.J. Nogales, A.J. Conejo // Journal of the Operational Research Society. - 2006. - V. 57, № 4. - P. 350-356.

5. Conejo, A.J. Day-Ahead Electricity Price Forecasting Using the Wavelet Transform and ARIMA Models / A.J. Conejo // IEEE Transaction on Power Systems. - 2005. - V. 20, № 2. - P. 1035-1042.

Вениамин Геннадьевич Мохов, доктор экономических наук, профессор, кафедра «Математическое и компьютерное моделирование», Южно-Уральский государственный университет (г. Челябинск, Российская Федерация), mokhovvg@susu.ru.

Татьяна Сергеевна Демьяненко, кандидат экономических наук, кафедра «Математическое и компьютерное моделирование», Южно-Уральский государственный университет (г. Челябинск, Российская Федерация), demianenkots@susu.ru.

Поступила в редакцию 20 марта 2020 2. 